\title{
PENDUGAAN KERAGAMAN GENETIK BERDASARKAN KOMPONEN HASIL PADA BEBERAPA GALUR PADI (Oryza sativa L.)
}

\section{GENETIC DIVERSITY ESTIMATION BASED ON YIELD COMPONENTS OF SOME RICE LINES (Oryza sativa L.)}

\author{
Miranda Ferwita Sari*, Jaenudin Kartahadimaja, Lina Budiarti, Destieka Ahyuni \\ Jurusan Budidaya Tanaman Pangan, Politeknik Negeri Lampung \\ Jl. Soekarno Hatta No. 10, Rajabasa Raya, Kec. Rajabasa, Bandar Lampung, Lampung 35144
}

*Korespondensi: mirandaferwita@polinela.ac.id

\begin{abstract}
ABSTRAK
Padi adalah salah satu komoditas pangan utama di Indonesia. Kebutuhan pangan beras akan meningkat setiap tahunnya selaras dengan peningkatan jumlah penduduk. Akan tetapi peningkatan kebutuhan beras tiap tahunnya tidak sesuai dengan kondisi lahan dan produksi padi yang ada saat ini. Salah satu upaya yang dapat dilakukan adalah dengan menggunakan galur atau varietas padi yang memiliki produktivitas tinggi. Penelitian ini bertujuan untuk menyeleksi galur-galur padi Rakitan Politeknik Negeri Lampung yang memiliki potensi produktivitas yang tinggi. Penelitian dilaksanakan di Lahan Seed Teaching Farm Program Studi Teknologi Perbenihan, Politeknik Negeri Lampung, pada bulan Agustus -Desember 2020. Penelitian disusun menggunakan rancangan acak kelompok lengkap RAKL dengan 1 faktor (galur), 3 blok, dan 5 ulangan. Perlakuan yang dicobakan adalah 13 galur tanaman padi rakitan Politeknik Negeri Lampung generasi ke-10, yaitu galur B1, B2, B3, B4, B7, D2, D3, F3, F4, H1, H4, K dan L2. Data hasil pengamatan diolah dengan software SAS dan terhadap analisis ragam yang nyata, dilanjutkan dengan menggunakan Uji Jarak Berganda Duncan (DMRT) dengan taraf kesalahan 5\%. Berdasarkan nilai KKG dan KKF, variabel pengamatan yang dapat digunakan untuk seleksi berdasarkan penelitian ini yaitu jumlah gabah bernas malai-1, jumlah gabah hampa malai-1 ${ }^{-1}$ bobot malai dan produktivitas. Galur yang memiliki produktivitas yang tinggi yaitu galur D3 dengan produktivitas 7,2 ton ha-1.
\end{abstract}

Kata kunci: galur padi, keragaman, produktivitas

\begin{abstract}
Rice is the one of main food commodities in Indonesia. The need for rice food will increase every year in line with the increasing population. However, the increase in the need for rice each year is not in accordance with the current conditions of land and rice production. One of the efforts that can be done is using lines that have high productivity. The developments of new rice lines have different characteristics. The research was conducted at the Seed Teaching Farm, Seed Technology, Politeknik Negeri Lampung in August-December 2020. The treatment design was arranged in randomized complete block design with 1 factor (line), 3 blocks, and 5 replications. The treatments tested were 13 rice plant lines of $10^{\text {th }}$ generation assembled by Politeknik Negeri Lampung, namely B1, B2, B3, B4, B7, D2, D3, F3, F4, H1, H4, K and L2. The observed data were processed with SAS software and the analysis of real variance was continued by using the Duncan's Multiple Range Test (DMRT) with a level of 5\%. Based on the KKG and KKF values, the observation variables that can be used for selection based on this study are the number of pithy grains panicles ${ }^{-1}$, the number of empty grains panicles ${ }^{-1}$, weight of panicles and productivity. The line that has high productivity is the D3 line with a productivity 7.2 ton ha-1.
\end{abstract}

Keywords: rice lines, diversity, productivity 


\section{PENDAHULUAN}

Padi adalah salah satu komoditas pangan utama di Indonesia. Kebutuhan akan beras meningkat setiap tahunnya selaras dengan peningkatan jumlah penduduk. Akan tetapi peningkatan kebutuhan beras tiap tahunnya tidak sesuai dengan kondisi lahan dan produksi padi yang ada saat ini. Menurut hasil survei kerangka sampel area BPS (2020), luas panen padi pada tahun 2019 mengalami penurunan sebesar 6,15 persen dibandingkan tahun 2018. Produksi padi pada 2019 mengalami penurunan sebesar 7,76 persen dibandingkan tahun 2018. Beberapa masalah yang menjadi penyebab persediaan beras di Indonesia setiap tahunnya berkurang karena adanya konversi lahan pertanian menjadi non pertanian, serangan hama dan penyakit, adanya perubahan iklim yang berdampak langsung pada sektor pertanian seperti peningkatan suhu, kandungan karbon dioksida, perubahan curah hujan dan lain-lainnya (Opalofia et al., 2018).

Peningkatan produksi padi dapat dilakukan dengan penggunaan galur atau varietas padi yang unggul yang memiliki produktivitas yang tinggi. Cara mendapatkan galur unggul yang memiliki produktivitas yang tinggi adalah dengan cara melakukan persilangan. Persilangan dilakukan untuk menggabungkan sifat-sifat genetik yang diinginkan, peningkatan dan pemanfaatan keragaman genetik dilanjutkan dengan seleksi dan evaluasi daya hasil. Bahan pemuliaan dapat berasal dari varietas lokal, varietas liar, varietas introduksi atau pun galur-galur homozigot (Kasno, 1992). Menurut Sasmita (2007), tujuan utama dari program pemuliaan saat ini adalah merakit suatu varietas unggul yang memiliki produktivitas dan kualitas hasil lebih baik, serta memiliki ketahanan baik terhadap cekaman biotik maupun abiotik.

Metode pemuliaan tanaman secara konvensional membentuk populasi kemudian dilakukan suatu seleksi terhadap populasi tersebut. Tanaman yang diperoleh dari hasil seleksi kemudian dilakukan pengujian dalam berbagai kriteria padi tipe baru PTB. Tujuan pemuliaan tanaman pada umumnya untuk meningkatkan produktivitas, salah satunya dengan meningkatkan jumlah bulir per malai (Purohit \& Mujumder, 2009). Perkembangan pemuliaan tanaman saat ini, selain pada peningkatan produksi juga mengarah pada pembentukan tanaman yang toleran terhadap cekaman lingkungan dan ketahanan terhadap serangan organisme penggangu tanaman 
serta peningkatan kualitas mutu (Saniyati, 2012).

Menurut Harahap (1989), terdapat beberapa metode persilangan buatan yang dapat dilakukan untuk mendapatkan varietas unggul padi, yaitu silang tunggal atau single cross (SC), silang puncak atau top cross (TC), silang ganda atau double cross (DC), silang balik atau back cross (BC), dan akhir-akhir ini dikembangkan pula metode persilangan multi cross (MC). Silang tunggal hanya melibatkan dua tetua saja. Silang puncak merupakan persilangan antara F1 dari silang tunggal dengan tetua lain. Silang ganda merupakan persilangan antara F1 dengan F1 hasil dari dua persilangan tunggal. Silang balik adalah persilangan F1 dengan salah satu tetuanya (Masniawati et al., 2006).

Program pemuliaan tanaman padi di Indonesia untuk meningkatkan potensial hasil dilakukan dengan pengembangan Padi Hibrida dan Padi Tipe Baru dengan perkiraan produktivitas mencapai 10-20\% lebih tinggi dibandingkan dengan varietas yang telah ada (Suhartatik, 2003). Menurut Abdullah et al. (2008) padi tipe baru khususnya pada lahan irigasi sangat penting untuk dikembangkan karena padi sawah irigasi adalah penghasil utama produksi beras nasional sehingga padi sawah tipe baru dapat meningkatkan produktivitas, produksi, dan pendapatan petani. Padi tipe baru merupakan varietas padi inbrida yang benihnya mudah untuk diproduksi sehingga harga benih dapat terjangkau oleh petani.

Sehingga pengembangan galur padi baru guna meningkatkan produktivitas sangat penting. Setelah mendapatkan beberapa galur hasil persilangan perlu dilakukan seleksi untuk menentukan galur terbaik yang bisa dikembangkan. Kegiatan seleksi dilakukan dengan mengamati karakter morfologi tanaman padi yang memiliki nilai koefisien keragaman genotipe yang luas. Sehingga tujuan penelitian ini adalah mengetahui karakter morfologi yang bisa digunakan untuk melakukan seleksi berdasarkan nilai koefisien keragaman genotipe dan fenotipenya. Tujuan kedua dari penelitian ini yaitu mengetahui galur padi rakitan Politeknik Negeri Lampung yang memiliki potensi hasil yang tinggi yang bisa dikembangkan.

\section{METODE PENELITIAN}

Penelitian ini dilaksanakan di lahan Seed Teaching Farm PS. Teknologi Perbenihan, Politeknik Negeri Lampung. Penelitian dilaksanakan pada bulan Agustus sampai dengan Desember 2020. Bahan yang digunakan dalam penelitian ini ada 13 galur padi rakitan Politeknik 
Negeri Lampung yaitu galur B1, B2, B3, B4, B7, D2, D3, F3, F4, H1, H4, K, dan L2. Dosis pemupukan yang diaplikasikan dalam penelitian ini yaitu urea $250 \mathrm{~kg}$ ha1, SP36 50 kg ha-1, dan KCl 50 kg ha-1.

Penelitian ini dilakukan dengan menggunakan Rancangan Acak Kelompok Lengkap (RAKL) faktor tunggal dengan perlakuan galur. Galur yang digunakan terdiri atas 13 galur galur PTB generasi ke-10 dengan 3 blok, sehingga berjumlah 39 satuan percobaan. Setiap satuan percobaan menggunakan jarak tanam $25 \mathrm{~cm} \times 25$ cm dengan 1 bibit per lubang tanam dengan jumlah populasi sebanyak 30 tanaman sehingga total luasan lahan setiap satuan percobaan seluas $300 \mathrm{~m}^{2}$. Dari setiap satuan percobaan diambil 5 tanaman yang digunakan sebagai tanaman sampel. Data hasil pengamatan diolah dengan software SAS dan terhadap analisis ragam yang nyata, dilanjutkan dengan menggunakan Uji Jarak Berganda Duncan (DMRT) dengan taraf kesalahan 5\%. Variabel pengamatan yang digunakan dalam penelitian ini antara lain panjang malai, jumlah gabah total malai ${ }^{-1}$, jumlah gabah bernas malai1 , jumlah gabah hampa malai ${ }^{-1}$, bobot malai, bobot gabah 1000 butir dan produktivitas. Perhitungan rumus koefisien keragaman genotipe (KKG) dan koefisien keragaman fenotipe (KKF) menurut Handayani \& Hidayat (2012) yaitu:

$$
\begin{aligned}
& K K G=\frac{\sqrt{\sigma^{2}} G}{X} \times 100 \% \\
& K K F=\frac{\sqrt{\sigma^{2}} F}{X} \times 100 \%
\end{aligned}
$$

Keterangan:

$\sigma^{2} \mathrm{G}=$ akar kuadrat varian genotipe

$\sigma^{2} \mathrm{~F}=$ akar kuadrat varian fenotipe

$\mathrm{X}=$ nilai contoh suatu sifat

Berdasarkan kriteria Moedjiono \& Mejaya (1994) dalam Herawati et al. (2009), KKF dan KKG dibagi dalam 4 kategori yaitu: rendah (KKG atau KKF < $25 \%)$, agak rendah $(25 \%<\mathrm{KKG}$ atau KKF $<50 \%)$, cukup tinggi $(50 \%<\mathrm{KKG}$ atau KKF $<75 \%)$, dan tinggi $(75 \%<$ KKG atau $\mathrm{KKF}<100 \%)$.

\section{HASIL DAN PEMBAHASAN}

Persilangan tanaman padi dilakukan dengan cara konvesional dari koleksi plasma nutfah yang ada. Seleksi dilakukan mulai generasi F2 hingga generasi lanjut untuk mendapatkan sifatsifat yang diinginkan. Sebanyak 13 galur merupakan hasil rakitan Politeknik Negeri Lampung yang kemudian dianalisis keragamannya. Salah satu cara untuk mengetahui keragaman adalah dengan mengamati karakter morfologi dari galur padi tersebut. 
Tabel 1. Karakter morfologi pada 13 galur padi

\begin{tabular}{rcccccccc}
\hline No & Galur & $\begin{array}{c}\text { PM } \\
\text { (cm) }\end{array}$ & JGTpM & JGBpM & JGHpM & BM (g) & $\begin{array}{c}\text { BG1000 } \\
\text { (g) }\end{array}$ & $\begin{array}{c}\text { Provitas } \\
\text { (ton ha } \mathbf{~ h}^{-1} \text { ) }\end{array}$ \\
\hline 1 & B1 & $27,78 \mathrm{a}$ & $180,78 \mathrm{ab}$ & $138,44 \mathrm{a}$ & $42,33 \mathrm{ef}$ & $37,67 \mathrm{abc}$ & $10,33 \mathrm{~cd}$ & $6,03 \mathrm{abc}$ \\
2 & B2 & $28,33 \mathrm{a}$ & $160,78 \mathrm{ab}$ & $75,44 \mathrm{ef}$ & $85,33 \mathrm{abc}$ & $28,22 \mathrm{bc}$ & $11,78 \mathrm{a}$ & $4,52 \mathrm{bc}$ \\
3 & B3 & $27,00 \mathrm{a}$ & $200,22 \mathrm{a}$ & $94,56 \mathrm{c}-\mathrm{f}$ & $105,67 \mathrm{a}$ & $31,11 \mathrm{abc}$ & $10,33 \mathrm{~cd}$ & $4,98 \mathrm{abc}$ \\
4 & B4 & $24,22 \mathrm{~b}$ & $163,56 \mathrm{ab}$ & $73,44 \mathrm{f}$ & $90,11 \mathrm{ab}$ & $24,56 \mathrm{c}$ & $10,22 \mathrm{~cd}$ & $3,93 \mathrm{c}$ \\
5 & B7 & $25,50 \mathrm{ab}$ & $155,50 \mathrm{~b}$ & $104,63 \mathrm{~b}-\mathrm{f}$ & $50,88 \mathrm{def}$ & $36,63 \mathrm{abc}$ & $10,50 \mathrm{bcd}$ & $5,86 \mathrm{abc}$ \\
6 & D2 & $24,56 \mathrm{~b}$ & $168,56 \mathrm{ab}$ & $113,89 \mathrm{a}-\mathrm{d}$ & $54,67 \mathrm{c}-\mathrm{f}$ & $42,22 \mathrm{ab}$ & $11,00 \mathrm{abc}$ & $6,76 \mathrm{ab}$ \\
7 & D3 & $26,67 \mathrm{a}$ & $169,00 \mathrm{ab}$ & $125,33 \mathrm{abc}$ & $43,67 \mathrm{ef}$ & $45,00 \mathrm{a}$ & $10,89 \mathrm{a}-\mathrm{d}$ & $7,20 \mathrm{a}$ \\
8 & F3 & $26,67 \mathrm{a}$ & $152,78 \mathrm{~b}$ & $105,56 \mathrm{~b}-\mathrm{e}$ & $47,22 \mathrm{ef}$ & $28,67 \mathrm{bc}$ & $9,89 \mathrm{~d}$ & $4,59 \mathrm{bc}$ \\
9 & F4 & $28,44 \mathrm{a}$ & $181,00 \mathrm{ab}$ & $113,11 \mathrm{a}-\mathrm{d}$ & $67,89 \mathrm{~b}-\mathrm{e}$ & $34,67 \mathrm{abc}$ & $11,44 \mathrm{ab}$ & $5,55 \mathrm{abc}$ \\
10 & H1 & $26,89 \mathrm{a}$ & $183,67 \mathrm{ab}$ & $101,89 \mathrm{~b}-\mathrm{f}$ & $81,78 \mathrm{a}-\mathrm{d}$ & $32,89 \mathrm{abc}$ & $11,00 \mathrm{abc}$ & $5,26 \mathrm{abc}$ \\
11 & H4 & $24,56 \mathrm{~b}$ & $151,67 \mathrm{~b}$ & $82,44 \mathrm{def}$ & $69,22 \mathrm{~b}-\mathrm{e}$ & $31,33 \mathrm{abc}$ & $10,22 \mathrm{~cd}$ & $5,01 \mathrm{abc}$ \\
12 & K & $25,78 \mathrm{ab}$ & $156,00 \mathrm{~b}$ & $86,22 \mathrm{def}$ & $69,78 \mathrm{~b}-\mathrm{e}$ & $35,78 \mathrm{abc}$ & $10,56 \mathrm{bcd}$ & $5,72 \mathrm{abc}$ \\
13 & L2 & $25,00 \mathrm{ab}$ & $154,22 \mathrm{~b}$ & $97,89 \mathrm{c}-\mathrm{f}$ & $56,33 \mathrm{c}-\mathrm{f}$ & $35,56 \mathrm{abc}$ & $10,11 \mathrm{~cd}$ & $5,69 \mathrm{abc}$ \\
\hline
\end{tabular}

Keterangan: PM (Panjang malai); JGTpM (Jumlah Gabah Total per Malai); JGBpM (Jumlah Gabah Bernas per Malai); JGHpM (Jumlah Gabah Hampa per Malai); BM (Bobot Malai); BG1000 (Bobot gabah 1000 butir); Provitas (Produktivitas); Angka-angka pada kolom yang sama diikuti oleh huruf yang sama, tidak berbeda nyata pada uji DMRT dengan tingkat signifikansi 5\%.

Karakter panjang malai merupakan salah satu faktor utama yang mendukung produktivitas karena malai yang panjang akan menghasilkan gabah lebih banyak. Panjang malai dibedakan menjadi 3 golongan berdasarkan ukurannya yaitu: (a) malai pendek berukuran $<20 \mathrm{~cm}$, (b) malai sedang berukuran $20 \mathrm{~cm}-30 \mathrm{~cm}$, dan (c) malai panjang berukuran $>30 \mathrm{~cm}$ (Siregar et al., 1998). Berdasarkan Tabel 1 karakter panjang malai tidak berbeda nyata pada semua perlakuan, semua galur yang diujikan dalam penelitian ini memiliki panjang malai berukuran sedang.

Jumlah gabah total adalah penjumlahan dari gabah bernas dan gabah hampa. Jumlah gabah total ini adalah potensi bulir padi yang dapat dihasilkan suatu galur. Apabila semua gabah total itu bernas maka potensi hasil galur tersebut akan semakin tinggi. Dari hasil analisis jumlah gabah total terbanyak ada pada galur B3 dan terendah pada galur H4. Jumlah gabah bernas tiap malai merupakan salah satu komponen hasil penting yang digunakan sebagai komponen seleksi untuk mengetahui kemampuan tanaman dalam berproduksi. Menurut Suhartini et al. (1999) komponen gabah bernas berkorelasi sangat nyata dengan hasil dan semua komponen hasil kecuali berat 1000 butir.

Nilai koefisien korelasi jumlah gabah bernas dengan hasil hampir sama dengan pengaruh langsungnya. Hal ini memberikan indikasi bahwa gabah 
bernas merupakan komponen seleksi yang efektif untuk mengetahui produktivitas. Dari hasil analisis jumlah gabah bernas terbanyak ada pada galur B1 dan jumlah gabah bernas paling sedikit ada pada galur B4. Gabah hampa yaitu gabah yang tidak terisi tepung karena kegagalan pengisian yang disebabkan oleh berbagai faktor, misalnya kekurangan nutrisi saat pengisian biji atau karena serangan hama penyakit. Banyak faktor yang mempengaruhi kehampaan butir gabah. Faktor-faktor tersebut seperti kerebahan, kurangnya intensitas sinar matahari, daun-daun mengering serta serangan hama dan penyakit yang menyebabkan rendahnya kemampuan padi untuk mengisi bulir-bulirnya (Marpaung, 2005). Pendapat lain menyebutkan bahwa banyaknya jumlah gabah hampa disebabkan oleh kurangnya unsur hara saat pengisian biji, seperti yang dikatakan oleh Siregar (1981) banyaknya gabah hampa dipengaruhi oleh kekurangan unsur N. Tanaman padi yang kekurangan nitrogen pertumbuhan menjadi kerdil, jumlah anakan sedikit dan bulir-bulir padi banyak yang kosong. Dari hasil analisis galur yang memiliki gabah hampa terbanyak yaitu galur B3.

Salah satu pertimbangan petani dalam memilih varietas padi yang akan dibudidayakan adalah besarnya potensi hasil yang akan diperoleh. Salah satu sifat yang bisa dilihat adalah bobot malai yang berkorelasi positif dengan banyaknya bulir dalam satu malai. Semakin berat bobot malai maka akan semakin banyak bulir yang ada dan semakin tinggi hasil yang akan didapat. Dari hasil analisis, galur yang memiliki bobot malai tertinggi adalah galur D3 dan yang terendah adalah galur B4.

Bobot 1000 butir gabah dari masing-masing galur dipengaruhi oleh kondisi setelah pembungaan, misalnya tersedianya zat makanan, baik atau buruknya cuaca dan jumlah daun. Kondisi tersebut akan mempengaruhi jumlah karbohidarat yang dihasilkan melalui proses fotosintesis dan selanjutnya akan menentukan ukuran gabah. Banyaknya penyerapan unsur hara mengakibatkan pengisian gabah secara sempurna dan menghasilkan bobot 1000 butir yang lebih tinggi. Dari hasil analisis, galur yang memiliki bobot 1000 butir tertinggi yaitu galur B2 dan yang terendah adalah galur F3.

Menurut Siregar et al. (1998) pentingnya mengetahui produktivitas adalah untuk mengetahui seberapa besar galur tersebut dapat menghasilkan. Hal ini dimungkinkan karena sifat genetis antara masing-masing galur atau varietas berbeda, maka dimungkinkan hasilnya akan berbeda. Peningkatan produksi berbanding lurus dengan peningkatan pertumbuhan relatif dan hasil bersih 
fotosintesis (Jumin, 1991). Dari hasil panen petak/ubinan kemudian dikonversi kedalam luasan 1 hektar. Hasil produksi dalam pertanaman ini tidak sesuai dengan hasil produksi di generasi sebelumnya karena banyak yang terserang hama tikus dan wereng sehingga banyak anakan rumpun-1 produktif yang tidak menghasilkan. Dari hasil analisis, produktivitas tertinggi ada pada galur D3 dan yang terendah pada galur B4.

Tabel 2. Nilai koefisien keragaman genotype dan koefisien keragaman fenotipe pada setiap variabel

\begin{tabular}{llcccc}
\hline No & Variabel Pengamatan & $\begin{array}{c}\text { KKG } \\
\mathbf{( \% )}\end{array}$ & Kriteria & $\begin{array}{c}\text { KKF } \\
\mathbf{( \% )}\end{array}$ & Kriteria \\
\hline 1 & Panjang malai & 9.84 & Rendah & 14.49 & Rendah \\
2 & Jumlah gabah total/malai & 12.63 & Rendah & 19.39 & Rendah \\
3 & Jumlah gabah bernas/malai & 31.20 & Agak rendah & 36.28 & Agak rendah \\
4 & Jumlah gabah hampa/malai & 55.11 & Cukup tinggi & 63.83 & Cukup tinggi \\
5 & Bobot malai & 21.18 & Rendah & 34.20 & Agak rendah \\
6 & Bobot gabah 1000 butir & 7.96 & Rendah & 9.90 & Rendah \\
7 & Produktivitas & 21.18 & Rendah & 34.20 & Agak rendah \\
\hline
\end{tabular}

Peningkatan variabilitas genetik merupakan aspek utama dalam program pemuliaan. Adanya variabilitas genetik yang tinggi proses seleksi dapat berlangsung efektif karena akan memberikan peluang yang lebih besar diperolehnya karakter-karakter yang diinginkan (Fauza et al., 2005). Berdasarkan Tabel 2, variabel yang memiliki keragaman genotipe dengan kriteria cukup tinggi yaitu jumlah gabah hampa malai ${ }^{-1}$. Variabel yang memiliki keragaman fenotipe cukup tinggi yaitu jumlah gabah hampa malai-1. Variabel lain yang bisa dijadikan acuan dalam seleksi yaitu jumlah gabah bernas malai1. Nilai variabilitas yang sempit menandakan setiap individu dalam populasi hampir seragam, sehingga peluang untuk mendapatkan generasi baru yang baik semakin sempit (Ruchjaniningsih, 2002). Hal tersebut karena pada penelitian ini menggunakan generasi ke-10 dengan harapan sudah menemukan galur harapan unggul yang bisa dilepas.

Jika nilai KKF rendah dan KKG tinggi maka keragaman lebih dipengaruhi oleh gen dan jika nilai KKF tinggi dan nilai KKG rendah menunjukkan bahwa keragaman lebih dipengaruhi oleh lingkungan. Menurut Prajitno et al. (2002), keragaman fenotipe yang tinggi disebabkan oleh adanya keragaman yang besar dari lingkungan dan keragaman genetik akibat segregasi. Keragaman yang 
teramati merupakan fenotipik yang dihasilkan karena perbedaan genotipe.

Hampir semua nilai KKF dalam penelitian ini lebih tinggi daripada nilai KKG. Menurut Jalata et al. (2011) nilai KKF yang lebih besar daripada KKG untuk karakter-karakter produksi mengindikasikan bahwa seleksi untuk peningkatan produksi dapat dilakukan berdasarkan penampilan fenotipik karakter-karakter tersebut. Meskipun demikian, KKF yang lebih besar daripada KKG juga menunjukkan bahwa keragaman yang muncul pada karakter tersebut lebih banyak dipengaruhi oleh faktor lingkungan daripada faktor genotipe (Gupta \& Verma 2000; Karnwal \& Singh 2009; Kumar \& Kamendar 2009), sehingga seleksi pada karakter tersebut dapat menyimpang (Gupta \& Verma 2000). Adapun nilai KKG yang mendekati atau hampir sama dengan KKF mengindikasikan bahwa faktor lingkungan hanya berpengaruh kecil terhadap keragaman yang terjadi pada karakter tersebut, sehingga seleksi dapat efektif dilakukan pada karakter tersebut berdasarkan penampilan fenotipiknya (Gupta \& Verma 2000; Aditya et al., 2011). Variabel pengamatan yang dapat digunakan untuk seleksi berdasarkan penelitian ini yaitu jumlah gabah bernas malai-1 ${ }^{-1}$ jumlah gabah hampa malai-1, bobot malai dan produktivitas karena memiliki keragaman genotipe yang lebih tinggi dibandingkan variabel lainnya.

\section{KESIMPULAN}

Berdasarkan penelitian yang telah dilakukan, dapat disimpulkan bahwa karakter morfologi yang dapat digunakan untuk seleksi berdasarkan penelitian ini yaitu jumlah gabah bernas malai $^{-1}$, jumlah gabah hampa malai-1, bobot malai dan produktivitas. Galur padi yang memiliki potensi untuk dikembangkan dengan nilai produktivitas yang tinggi yaitu galur D3 dengan produktivitas 7,2 ton ha-1.

\section{UCAPAN TERIMA KASIH}

Penulis mengucapkan terima kasih kepada Teaching Farm Produksi Benih Padi dan Jagung Program Studi Teknologi Perbenihan yang telah memberikan bahan galur padi dan tempat untuk melaksanakan penelitian.

\section{DAFTAR PUSTAKA}

Abdullah, B, Tjokrowidjojo, S, \& Sularjo. (2008). Status, perkembangan, dan prospek pembentukan padi tipe baru di Indonesia. Prosiding Simposium $V$ Tanaman Pangan; Inovasi Teknologi Tanaman Pangan. Penelitian dan Pengembangan Padi. Bogor.

Aditya, J. P, Bhartiya, P \& Bhartiya, A. (2011). Genetic variability, heritability, and character 
association for yield and component characters in soybean (Glycine $\max$ (L.) Merrill). J. Central Europ. Agric. 12(1), 27-34.

BPS. (2020). Luas panen dan produksi padi di Indonesia 2019. Berita Resmi Statistik No. 16/02/Th. XXIII.

URL:https://www.bps.go.id/pres srelease/2020/02/04/1752/luas -panen-dan-produksi-padi-padatahun-2019-mengalamipenurunan-dibandingkan-tahun2018-masing-masing-sebesar-615-dan-7-76-persen.html. (diakses pada tanggal 31 Agustus 2020).

Fauza H., Karmana, M. H., Rosti, N, \& Mariska, I. 2005. Pertumbuhan dan variabilitas fenotipik manggis hasil iradiasi sinar gamma. J. Zuriat 16(2), 133-144.

Gupta, S. K \& Verma, S. R. (2000). Variability, heritability, and genetic advance under normal and rainfed conditions in durum wheat (Triticum durum Desf). Indian J. Agric. Res. 34(2), 122125.

Handayani, T, \& Hidayat, I. M. (2012). Keragaman genetik dan heritabilitas beberapa karakter utama pada kedelai sayur dan implikasinya untuk selesi perbaikan produksi. J. Hort. 22(4), 327-333.

Harahap, Z, \& Silitonga, T. S. (1989). Perbaikan varietas padi dalam Padi Buku 2. Pusat Penelitian dan Pengembangan Tanaman Pangan. Bogor.

Herawati, R., Purwoko, B. S, \& Dewi, I .S. (2009). Keragaman genetik dan karakter agronomi galur haploid ganda padi gogo dengan sifatsifat tipe baru hasil kultur antera. Jurnal Agronomi Indonesia 37(2), 87-94.
Jalata, Z, Ayana, A \& Zeleke, H. (2011). Variability, heritability, and genetic advance for some yield and yield realated traits in Ethiopian Barley (Hordeum vulgare L.) landraces and crosses. Int. J. Plant Breeding and Genet, 5(1), 44-52.

Jumin, H. B. (1991). Dasar-dasar Agronomi. Rajawali Press. Jakarta.

Karnwal, M. K \& Singh. (2009). Studies on genetic variability, character association and path coefficient for seed yiled and its contributing traits in soybean (Glycine max (L.) Merrill). Legume Res. 32(1), 7073.

Kasno. (1992). Pemuliaan Tanaman Kacang-kacangan. Balai Penelitian Tanaman Pangan. Malang.

Kumar, K. M \& Kamendra, S. (2009). Studies on genetic variability, character association and path coefficient for seed yield and its contributing traits in sybean (Glycine max (L.) Merrill). Legume Res. 32(1), 70-73.

Marpaung, F. A. (2005). Studi keragaman morfologi beberapa galur padi (Oryza sativa L.). Skripsi. Fakultas Pertanian, Universitas Sebelas Maret, Surakarta.

Masniawati, A. (2006). Karakteristik plasma nutfah padi aromatik Sulawesi Selatan. Buletin Penelitian seri Hayati, 9(2006), 107-114.

Moedjiono, \& Mejaya, M. J. (1994). Variabilitas genetik beberapa karakter plasma nutfah jagung koleksi Balittan Malang. Zuriat 5(2), 27-32.

Opalofia, L, Yusniwati, \& Swasti, E. (2018). Droght tolerance in some of red rice line based on morphology at vegetative stage. 
International Journal of

Environment, Agriculture and

Biotechnology, 3(6),1995-2000.

Prajitno, D, Rudi, H. M, Purwantoro, A, \& Tamrin. (2002). Keragaman genotip salak lokal Sleman. Habitat, 8(1), 57-65.

Purohit, S, \& Majumder, M. K. (2009). Selection of high yield rice variety from a cold tolerant threewayrice (Oryza sativa L.) cross involving Indica, Japonica, and wide compatible variety. MiddleEast J. Sci. Res, 4(1),28-31.

Ruchjaniningsih, R, Setiamihardja, M. H, Karmana, \& Jaya, W. M. (2002). Efek mulsa pada variabilitas genetik dan heritabilitas ketahanan terhadap ralstonia solanacearum pada 13 genotip kentang di dataran medium Jatinangor. J. Zuriat, 13(2), 73-80.

Saniyati, A. (2012). Uji daya hasil pendahuluan 100 galur zuriat F5 padi tipe baru hasil dari kombinasi 3 persilangan IPB117F-5-1-1 x IR 64, IPB98-F-5-1-1 x IR 64, dan Cimelati x IPB97-F-31-
1-1. Skripsi. Fakultas Pertanian, Institut Pertanian Bogor, Bogor.

Sasmita, P. (2007). Aplikasi teknik kultur antera pada pemuliaan tanaman. Balai Besar Tanaman Padi, Sukamandi.

Siregar, H. (1981). Budidaya tanaman padi di Indonesia. Sastra Hudaya, Jakarta.

Siregar, H, Endang, S, \& Soewito. (1998). Analisis beberapa sifat galur padi sawah dua musim tanam pusakanegara. Penelitian Pertanian Tanaman Pangan, 17(1), 38-44.

Suhartatik, E. (2003). Teknik pemupukan nitrogen untuk padi tipe baru dan padi hibrida. J. Puslitbangtan, 28(2003),4-5.

Suhartini, Darajat, T., Warsono, A. A., \& Hardjasa, W. S. (1999). Analisis korelasi dan koefisien lintas hasil padi sawah pada lahan keracunan Fe. Penelitian Pertanian Tanaman Pangan, 18(2),23-27. 